\title{
The growth cycle of Simkania negevensis
}

\author{
Simona Kahane, Nina Kimmel and Maureen G. Friedman
}

Department of Virology, Faculty of Health Sciences, Ben Gurion University of the Negev, PO Box 653, Beer Sheva, Israel 84105-IL

\author{
Author for correspondence: Maureen G. Friedman. Tel: +972 8 6403857. Fax: +97286276215. \\ e-mail: maureen@bgumail.bgu.ac.il
}

Keywords: Chlamydia-like micro-organism, infectivity, Simkania

\section{INTRODUCTION}

Simkania negevensis, formerly referred to as 'the microorganism Z' or 'Simkania Z', has been associated with community-acquired pneumonia in adults (Lieberman et al., 1997) and with bronchiolitis in infants (Kahane et al., 1998). Exposure to the organism is widespread in the Negev region of Israel (Friedman et al., 1999), in Vancouver, BC, Canada, in Brooklyn, NY, and in Lima, Peru (unpublished data). Members of two other families in the Chlamydiales, the well-studied Chlamydiaceae and the family of Parachlamydiaceae, have also been associated with respiratory disease (Schachter, 1999; Birtles et al., 1997). Knowledge of the in vitro growth cycle and molecular traits of novel intracellular bacteria may shed light on pathological and epidemiological processes associated with infection by the org-

Abbreviations: EB, elementary body; EM, electron microscopy; IFU, infectious-centre-forming unit; p.i., post-infection; PIPA, plate immunoperoxidase assay; RB, reticulate body. anisms, and may have implications for the development of effective treatment and prevention strategies.

It has been proposed that Simkania negevensis be assigned to the new family Simkaniaceae, in the order Chlamydiales, based on its intracellular bimorphic parasitic growth in cultured cells and on rDNA sequence comparisons (Kahane et al., 1999; Everett et al., 1999). Its genome length is $1.7 \mathrm{Mbp}$, compared to $1 \cdot 0-1 \cdot 2 \mathrm{Mbp}$ for members of the family Chlamydiaceae (Kahane et al., 1999); its full-length $16 \mathrm{~S}$ and $23 \mathrm{~S} \mathrm{rDNA}$ sequences are each $80-87 \%$ identical to those of members of the Chlamydiaceae, whereas all members of the Chlamydiaceae have $>90 \%$ identity with each other. [Members of the genus Chlamydia have $>95 \%$ identity with each other; members of the genus Chlamydophila have $\geqslant 95 \%$ identity with each other (Everett et al., 1999).]

Parachlamydiaceae, Chlamydiaceae, Simkania negevensis and other Chlamydia-like bacteria placed in the order Chlamydiales exhibit some variation in their developmental morphology. In Chlamydiaceae, the infectious elementary body (EB) is an electron-dense, coccoid 
body, $0 \cdot 2-0 \cdot 35 \mu \mathrm{m}$ in size (Rake, 1957). It changes into a replicating form that is $0 \cdot 8 \mu \mathrm{m}$ in size and can be seen 7-9 h after infection of a host cell (Rake, 1957). This irregularly shaped replicative form is called the 'reticulate body' (RB), because it is 'composed of amorphous or reticulated material with moderate density' (Higashi et al., 1962; Higashi, 1965). For reasons that are not well-understood, the Chlamydiaceae RB is not infective and does not survive long outside of the host cell. One to three days after infection [depending on the strain and the multiplicity of infection (m.o.i.)], most RBs have reorganized back into EBs and are released either by host-cell lysis or by fusion of the phagocytic inclusion with the cell wall. A method that has been invaluable in elucidating the replication cycle and in characterizing the developmental forms in Chlamydiaceae is the purification of EBs and RBs using Renografin density gradients (Caldwell et al., 1981; Barbour et al., 1982). Pleomorphic Simkania negevensis forms, some of which are reticulated and large $(0 \cdot 3-0.7 \mu \mathrm{m})$ and some of which have electron-dense and electron-lucent areas, can be selectively fractionated on density gradients in much the same way as Chlamydiaceae spp. bodies (Kahane et al., 1999). The purpose of this study was to describe the Simkania negevensis growth cycle in vitro and compare it with that of its close relatives, the Chlamydiaceae. In keeping with the degree of rDNA sequence divergence observed between members of the two families, it was expected that both similarities and differences would be found.

\section{METHODS}

Growth of organisms and standard purification procedure. Vero cells were grown in RPMI medium supplemented to $15 \%$ with fetal calf serum, $1 \%$ glucose, $100 \mathrm{U}$ penicillin $\mathrm{ml}^{-1}$, $100 \mu \mathrm{g}$ streptomycin $\mathrm{ml}^{-1}, 1 \cdot 2 \mu \mathrm{g}$ nystatin $\mathrm{ml}^{-1}, 8 \mu \mathrm{g}$ gentamicin $\mathrm{ml}^{-1}$ and $50 \mu \mathrm{g}$ vancomycin $\mathrm{ml}^{-1}$. Simkania negevensis ATCC VR-1471 ${ }^{\mathrm{T}}$ was grown in Vero-cell cultures in the presence of $1 \mu \mathrm{g}$ cycloheximide $\mathrm{ml}^{-1}$. For the standard purification procedure cultures were harvested with glass beads between 7 and 15 days after infection and mildly sonicated; cell debris was removed by centrifugation for $10 \mathrm{~min}$ at $1000 \mathrm{~g}$. Simkania negevensis organisms were purified on Urografin gradients as follows. After removal of cell debris by low-speed centrifugation, the bacterial suspension was centrifuged through a $35 \%(\mathrm{v} / \mathrm{v})$ Urografin 'cushion' (30 min at $54000 \mathrm{~g}$ ) in an SW 28 Beckman rotor. The pellet was resuspended in HEPES $(25 \mathrm{mM})$ saline buffer and layered onto a discontinuous $(40 / 44 / 52 \%, \mathrm{v} / \mathrm{v})$ Urografin gradient in HEPES saline buffer. After centrifugation for $45 \mathrm{~min}$ at $54000 \mathrm{~g}$, interface bands were removed by puncturing the gradient tube and were diluted in HEPES-saline; particles were then sedimented by further centrifugation $(30 \mathrm{~min}$ at $54000 \mathrm{~g}$ ). Control studies were carried out separately under identical conditions using Chlamydia trachomatis L2/434/BU.

Fixation and staining of infected cell monolayers for observation under light microscopy. Vero cell cultures were grown in Nunclon SlideFlasks and infected with Simkania negevensis (the $44 / 52 \%$ Urografin gradient fraction) at an m.o.i. of $0 \cdot 3$. At various times post-infection (p.i.) monolayers were washed with PBS $(\mathrm{NaCl}, 0.137 \mathrm{M}$; KCl, 0.0027 M;
$\mathrm{Na}_{2} \mathrm{PO}_{4}, 0.008 \mathrm{M} ; \mathrm{KH}_{2} \mathrm{PO}_{4}, 0.00147 \mathrm{M} ; \mathrm{pH} 7 \cdot 2$ ), fixed for $3 \mathrm{~min}$ in May-Grünwald solution (MG-500, Sigma), washed three times with distilled water and further stained for $25 \mathrm{~min}$ with Giemsa stain (GS-500, Sigma) diluted to $27 \%$ (v/v) with distilled water. After washing with tap water, the Nunclon flasks were taken apart, and the slide portion was examined by light microscopy and the image photographed.

Infectivity assays for Simkania negevensis. For growth curves, monolayers of Vero cells in replicate $25 \mathrm{~cm}^{2}$ flasks were inoculated with Simkania negevensis. At various times after infection cells were scraped into the medium with glass beads; the suspensions were frozen at $-70{ }^{\circ} \mathrm{C}$ with $50 \%$ fetal calf serum. The number of infectious-centre-forming units (IFUs) for each sample was determined by 10 -fold dilution and infection of Vero cells cultured in 96-well plates. Three days p.i. the plates were fixed in $95 \%$ ethanol for $10 \mathrm{~min}$ at room temperature and examined for IFUs by the microtitre 'plate immunoperoxidase assay' (PIPA), performed as described previously (Kahane et al., 1998). Briefly, after fixation, plates were incubated for $1 \mathrm{~h}$ at $37^{\circ} \mathrm{C}$ with Simkania negevensisspecific antisera raised in rabbits, washed and re-incubated $\left(1 \mathrm{~h}, 37^{\circ} \mathrm{C}\right)$ with swine anti-rabbit horseradish-peroxidaseconjugated antibodies, and after another wash, stained with diaminobenzidine as substrate. Infectious centres were counted under a magnification of $\times 200$ with an inverted microscope, and the counts for three wells were averaged; the IFU ml ${ }^{-1}$ count for the original sample was then calculated.

Titration of infectivity. Simkania negevensis particles that banded at the $40 / 44 \%$ interface and at the $44 / 52 \%$ interface of a Urografin density gradient upon centrifugation were directly examined in two ways: (1) by titration on Vero cells to determine the number of IFUs in each fraction, and (2) by enumeration of aliquots mixed with known concentrations of polystyrene latex beads by negative-stain electron microscopy (EM). Replicative forms and electron-dense forms of the bacteria present in both fractions were determined by photography of random EM thin-section fields and by counting samples of several hundred particles. The relative infectivity of the constituents of each fraction was determined.

\section{EM}

Negative staining. Purified Simkania negevensis particles suspended in $25 \mathrm{mM}$ HEPES saline buffer were homogeneously mixed with polystyrene latex particles (mean diameter $0 \cdot 175 \mu \mathrm{m}$, at $3.51 \times 10^{11}$ particles $\mathrm{ml}^{-1}$; Agar Scientific) and applied to a 400-mesh copper Formvar/carbon-coated grid which was fixed and stained as described by Glauert (1975). Briefly, the grids were dipped for $15 \mathrm{~s}$ in paraformaldehyde/ glutaraldehyde fixative and then three times in distilled water, followed by staining in $2 \%$ ammonium molybdate solution, $\mathrm{pH} 7 \cdot 4$. Negative staining was used to count total particle numbers, without discrimination as to the type of the particle.

Thin sections of cultured cells or gradient-fractionated bacteria. Infected cells were scraped from flasks and pelleted, or bacteria were fractionated on discontinuous Urografin gradients. These preparations were fixed, embedded in Araldite, and stained for EM as described by Biberfeld (1971). The larger morphological forms, $0 \cdot 3-0 \cdot 7 \mu \mathrm{m}$, were designated 'replicative' forms for the following reasons: (i) they were the first forms to appear after infection; (ii) they multiplied rapidly and were often captured apparently in the process of binary division; and (iii) they contained reticulated, homogeneously stained material and no white, unstained or electron-dense areas. The smaller particles, $0 \cdot 2-0 \cdot 3 \mu \mathrm{m}$, were designated 'electron-dense' forms because they contained at least some 

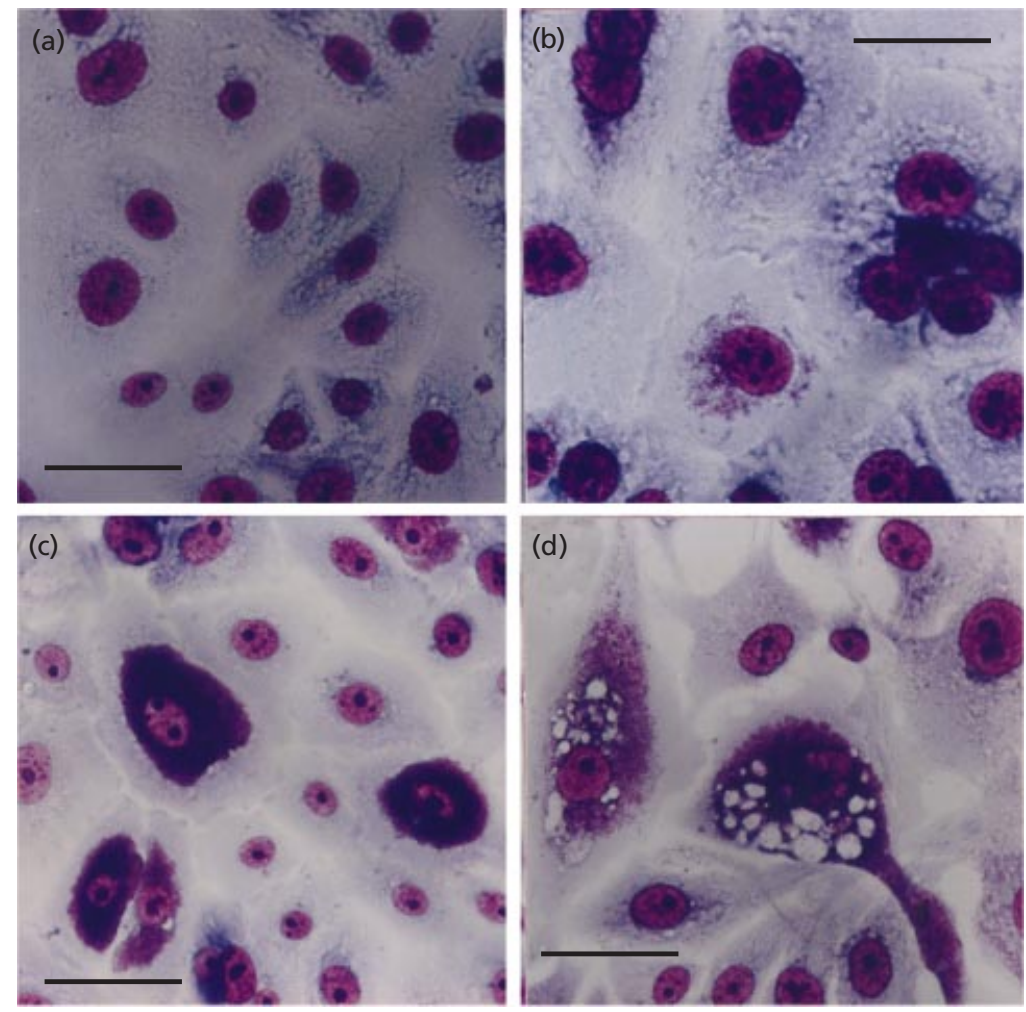

Fig. 1. Vero-cell monolayers fixed and stained with May-Grünwald/Giemsa at various times after infection with Simkania negevensis. (a) Uninfected cells; (b) 2 days; (c) 5 days; (d) 13 days. Bar, $50 \mu \mathrm{m}$. electron-dense material with or without an electron-lucent area and no reticulated material (Kahane et al., 1993). Typically, 8-10 randomly chosen EM fields of sectioned infected cells were photographed, and several hundred particles were counted from the photographs of each Urografin fraction to determine the relative proportion of the morphological forms.

Chlamydia trachomatis EB and RB infectivity. The infectivity of Chlamydia trachomatis EBs and RBs prepared on discontinuous Urografin gradients was assessed as a control for the Simkania negevensis experiments. Chlamydia trachomatis-infected cells were identified in the PIPA by using polyclonal rabbit antisera raised against Chlamydia trachomatis (Gonen et al., 1993).

\section{RESULTS}

\section{Light microscopy studies}

It was previously reported (Kahane et al., 1999) that the replication cycle of Simkania negevensis, as observed by phase-contrast microscopy, takes about 12-15 days, whereas Chlamydia trachomatis-infected (and other Chlamydiaceae-infected) cells detach from the monolayer and lyse as early as 2-3 days after infection. To observe in detail the growth of Simkania negevensis in cell culture, Vero cells were infected at an m.o.i. of $0 \cdot 3$, then fixed and stained at various times. Fig. 1(a) shows uninfected cells and Fig. 1(b-d) shows cells infected for 2, 5 and 13 days, respectively. It appeared that infection did not readily extend to neighbouring cells within the experimental time window. Infected cells could be distinguished from uninfected cells by the presence of dark (mostly perinuclear) patches in the cytoplasm. With increasing time after infection, these patches built up into masses which occupied a large proportion of the cytoplasm of the cell (Fig. 1c), and at later times large vacuoles appeared which seemed to be empty (Fig. 1d). However, when such vacuoles were seen by phasecontrast microscopy, they often contained fine, rapidly moving particles (not shown). These observations were in agreement with studies carried out at higher m.o.i. values (Kahane et al., 1999). In control studies, carried out under identical conditions using Chlamydia trachomatis, infected cells detached from the monolayer and lysed $2-3$ days p.i.

\section{Morphology of particles and inclusions}

The electron-dense area in Simkania negevensis particles began to appear on day 3 p.i. and was located to only one side of each coccoid or slightly elongated $0 \cdot 2-0 \cdot 3 \mu \mathrm{m}$ particle. Each particle almost always contained some amorphous electron-lucent areas as well. Replicative forms of Simkania negevensis resembled RBs of other chlamydiae in size $(0.3-0.7 \mu \mathrm{m})$, in homogeneity and in light staining (Fig. $2 \mathrm{~b}-\mathrm{f}$ ). They were somewhat pleomorphic in shape and were the only form that was ever seen undergoing binary fission. Particles whose appearance was consistent with being in transition between these two morphological types were also seen in EM thin sections; in Urografin gradients these intermediate forms banded at both the $40 / 44 \%$ and the $44 / 52 \%$ Urografin gradient interfaces. In contrast to Chlamydia trachomatis, where only one inclusion body is observed 

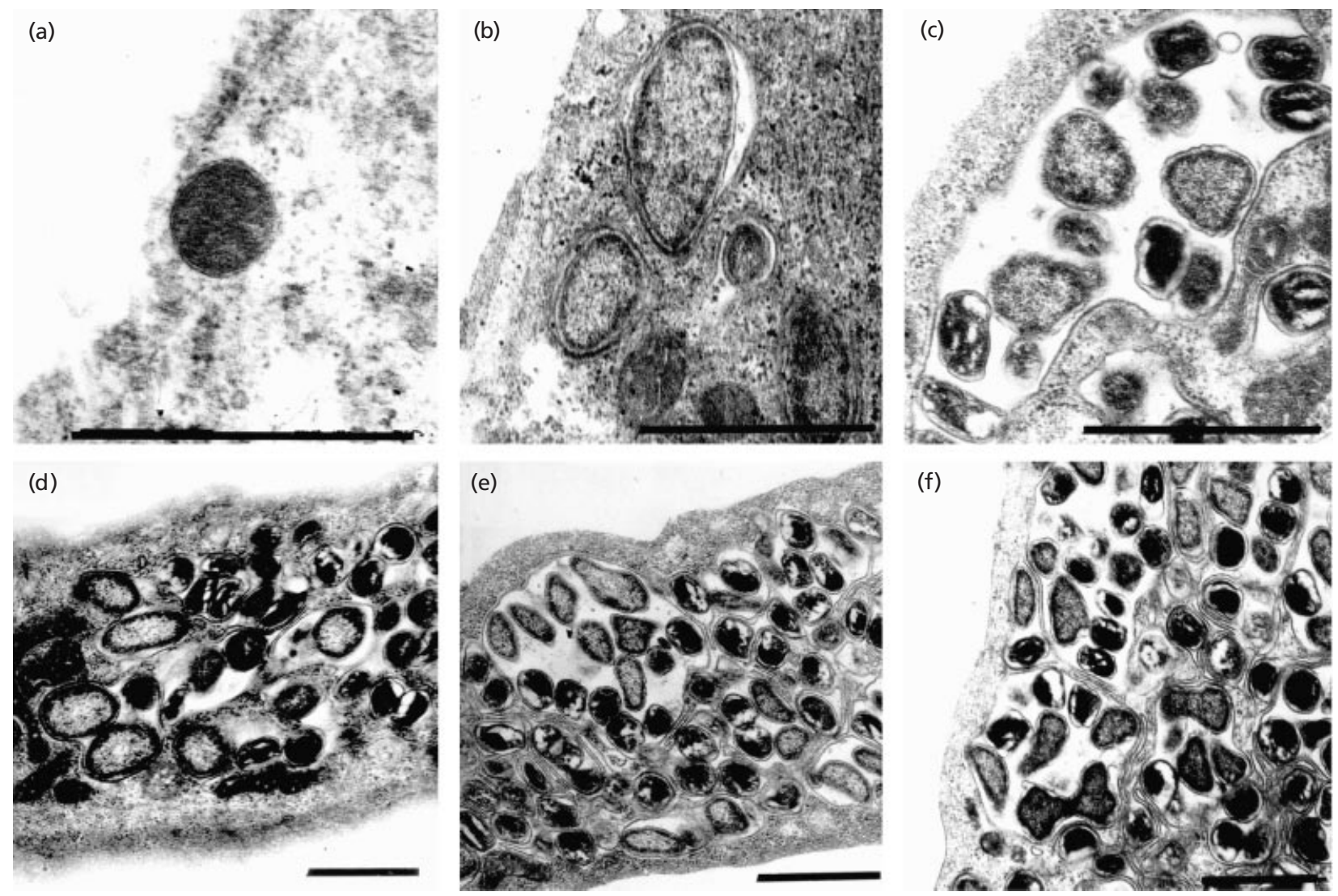

Fig. 2. Electron micrographs of thin sections of Vero cells infected with purified Simkania negevensis 40/44\% fraction, fixed and embedded at various times after infection. (a) 1 day; (b) 2 days; (c) 3 days; (d) 6 days; (e) 9 days; (f) 12 days. Bars, $1 \mu \mathrm{m}$.

in light microscopy or electron micrographs, electron micrographs of Simkania negevensis-infected cells showed many small inclusions (Fig. 2e, f) close and intertwining, especially late in infection.

\section{Kinetics of production and release of progeny infectious organisms}

It had been shown previously that when the majority of cells in a culture were infected with Simkania negevensis, the growth curve of progeny IFUs had an exponential phase and a plateau (Kahane et al., 1999). Since high titres of infectious particles were detectable already at 2-3 days p.i., it was of interest to determine whether in cultures infected at very low input m.o.i. values, particles produced at early times would initiate further cycles of infection. Fig. 3 shows that a somewhat longer lag period and a lower plateau level were found with decreasing input m.o.i., and that further cycles of infection were apparently not initiated. Infection of other cell lines (e.g. HEp-2) with Simkania negevensis resulted in similar growth kinetics, namely a plateau stage following relatively brief exponential growth. No evidence of cell lysis was visible in culture bottles, even 12-15 days p.i. When supernatants of cultures infected at an m.o.i. of $0 \cdot 1$ were tested for the presence of infectious particles as a function of time, to find evidence for the release of infectious particles from cells, no infectious particles were found in the culture medium during the first 3 days p.i.; thereafter the level of particles in the culture medium was, at each time point, less than one-thousandth of the total level of infectious particles in the culture (measured in parallel in replicate cultures). Thus, either less than one infected cell in a thousand lysed or any given infected cell released less than one one-thousandth of its progeny infectious particles into the culture medium.

\section{Growth curves of density-gradient-fractionated Simkania negevensis}

Separation of Simkania negevensis morphological forms on Urografin gradients produced bands at the $40 / 44 \%$ interface and at the $44 / 52 \%$ interface; exactly the same was observed for Chlamydia trachomatis EBs and RBs under identical conditions in control studies. Material from both fractions was examined by transmission EM, titrated by PIPA to determine the number of IFU ml${ }^{-1}$, and used immediately to initiate growth in fresh monolayers. Particles in transition between the electrondense and replicative form were evident in both bands, according to EM. EM also indicated that the flasks 


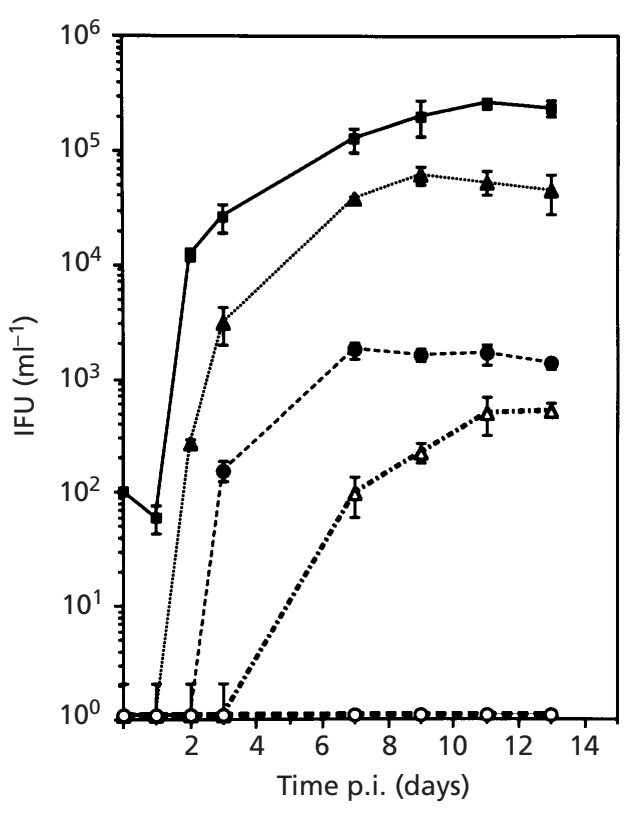

Fig. 3. Growth curves of Simkania negevensis on Vero cells at various m.o.i. values. Cells were infected with gradientfractionated electron-dense bacteria at the m.o.i. values indicated and harvested at the time points indicated. Each culture was titrated on Vero-cell monolayers by PIPA. m.o.i. values: $\square, 0.5 ; \Delta, 0.05 ; 0,0.005 ; \triangle, 0.0005,0,0.00005$. Bars indicate the standard deviation from the mean for triplicate wells at each time point. The upper curve was previously published as Fig. 1 in Kahane et al. (1999).

infected with the $44 / 52 \%$ fraction received 8.4 times as many electron-dense particles as the flasks infected with the $40 / 44 \%$ fraction. The m.o.i., however, as determined in parallel by PIPA titration (IFU ml ${ }^{-1}$ ), was $2 \cdot 8$ for the $44 / 52 \%$ inoculum and 1.2 for the $40 / 44 \%$ inoculum (Fig. 4). The growth curves of the $44 / 52 \%$ inoculum and the $40 / 44 \%$ inoculum were practically superimposable, which would not be expected if one fraction had eight times as many infectious particles as the other (cf. Fig. 3).

To investigate the infectivity of Simkania negevensis particles in Vero-cell cultures, fresh preparations of the $40 / 44 \%$ or the $44 / 52 \%$ Urografin fractions were used to inoculate cell monolayers at an m.o.i. of $0 \cdot 1$. When cultures were infected with the $44 / 52 \%$ inoculum, electron-dense particles could be seen at $17-24 \mathrm{~h}$ p.i. (not shown). The growth cycle resulting from the $40 / 44 \%$ inoculum was followed by both EM and by infectivity assays (Figs 2 and 5). EM of cells infected with the $40 / 44 \%$ Urografin fraction showed only one inclusion body early in infection (17 and $20 \mathrm{~h}$, and up to 1-2 days) that typically contained one or, infrequently, two replicating bacteria. By day 3, replicative forms were numerous and only an occasional electron-dense body was present (Fig. 2c). Subsequently, inclusions could be found that contained diverse particles in various stages of development. By 6, 9 and 12 days p.i., the total number of intracellular particles had increased

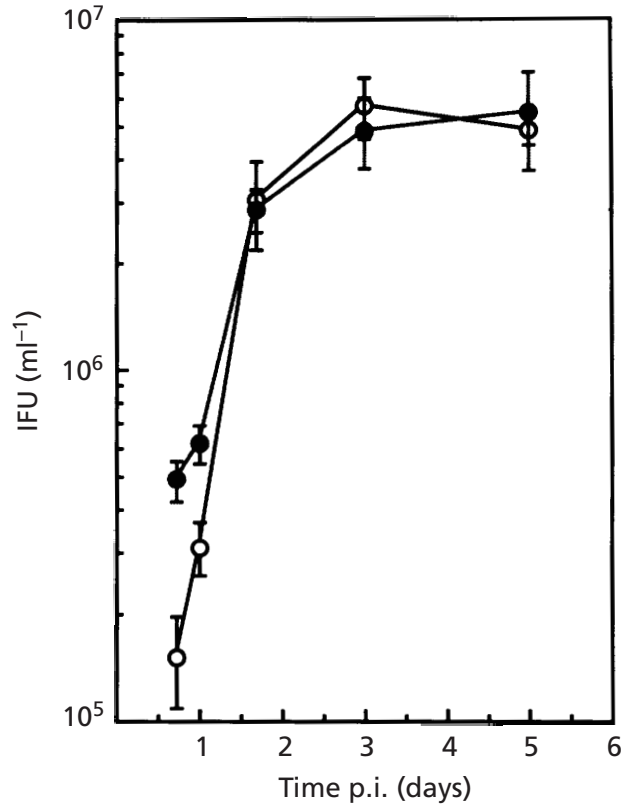

Fig. 4. Growth curves of Simkania negevensis in Vero cells infected with $44 / 52 \%(\bullet)$ and $40 / 44 \%(\bigcirc)$ Urografin fractions at an m.o.i. of 2.8 and 1.2 , respectively. IFU values were determined by PIPA. Bars indicate the standard deviation from the mean for triplicate wells at each time point.

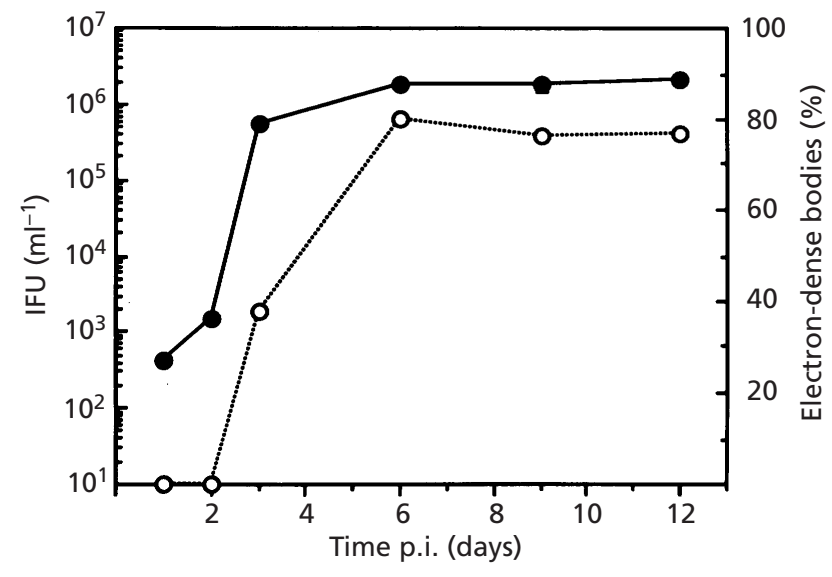

Fig. 5. Kinetics of the appearance of infectious particles (0) after inoculation of Vero-cell monolayers with purified Simkania negevensis $40 / 44 \%$ inoculum and the proportion of electron-dense particles to total cellular particles as counted from electron micrographs of thin sections of the infected cells (O). Bars (most are not visible) indicate the standard deviation from the mean for triplicate wells at each time point.

greatly, with the proportion of electron-dense bacteria rising rapidly (Fig. 5, right vertical axis). Some replicative forms with irregular morphology were present at 12 days p.i. (Fig. 2f). The proportion of electron-dense to replicative forms in several electron micrographs photographed at random for each time point is represented in Fig. 5. Total particle counts ranged from 500 to 1000 for 
Table 1. Data used to calculate infectivity not explained by electron-dense bacteria in $40 / 44 \%$ Urografin fractions of Simkania negevensis or by EBs in 40/44 \% Urografin fractions of Chlamydia trachomatis (representative experiments)

\begin{tabular}{|c|c|c|c|c|c|c|c|}
\hline \multirow[t]{2}{*}{ Organism } & \multirow{2}{*}{$\begin{array}{c}\text { Urografin } \\
\text { fraction }(\%)\end{array}$} & \multirow{2}{*}{$\begin{array}{l}\text { Total no. } \\
\text { particles }\end{array}$} & \multirow[t]{2}{*}{ IFU } & \multicolumn{2}{|c|}{ Particle proportions* } & \multirow{2}{*}{$\begin{array}{c}\text { Infectivity accounted } \\
\text { for by dense } \\
\text { bacteria }(\%) \dagger\end{array}$} & \multirow{2}{*}{$\begin{array}{l}\text { Unexplained } \\
\text { infectivity } \mathbb{S}\end{array}$} \\
\hline & & & & Dense & Replicative & & \\
\hline \multirow[t]{2}{*}{ Simkania negevensis } & $44 / 52$ & $5 \cdot 7 \times 10^{9}$ & $3 \cdot 13 \times 10^{9}$ & $90 \cdot 1$ & $9 \cdot 9$ & $100 \ddagger$ & - \\
\hline & $40 / 44$ & $6.9 \times 10^{9}$ & $2 \cdot 5 \times 10^{9}$ & $25 \cdot 2$ & $74 \cdot 8$ & 42 & $58 \%$ \\
\hline \multirow{2}{*}{ Chlamydia trachomatis } & $44 / 52$ & $5 \times 10^{10}$ & $3.4 \times 10^{8}$ & $92 \cdot 0$ & $8 \cdot 0$ & $100 \ddagger$ & - \\
\hline & $40 / 44$ & $3 \cdot 8 \times 10^{10}$ & $2 \cdot 3 \times 10^{6}$ & $9 \cdot 0$ & $91 \cdot 0$ & 100 & - \\
\hline
\end{tabular}

* As determined by EM.

† The ratio of electron-dense particles : IFUs determined for the $44 / 52 \%$ Urografin fractions were assumed to be valid for electron-dense bacteria in the $40 / 44 \%$ Urografin band as well.

$\ddagger$ Per definition.

$\mathbb{S}-$, No unexplained infectivity, either by calculation or by definition.

each time point between 6 and 12 days. For days 1, 2 and 3 , total particle counts were 15, 32 and 104, respectively.

Simkania negevensis particles in the Urografin fractionated inocula were enumerated by EM. As shown in Table 1, not all of the infectivity in the $40 / 44 \%$ fraction could be accounted for by electron-dense bacteria, as enumerated by EM. In four repetitions of the experiment, the level of infectivity not accounted for ranged from 48 to $94 \%$. Identical control studies were carried out in several replicate experiments using Chlamydia trachomatis. In these experiments all of the infectivity in the $40 / 44 \%$ fraction was accounted for by the number of EBs present, whether the proportion of EBs in the fraction was minimal or substantial.

\section{DISCUSSION}

This is the first detailed account of the developmental cycle of a Chlamydia-like bacterium that does not belong to the family Chlamydiaceae. The growth cycle of Simkania negevensis was found to be similar to that of members of the well-known family of the Chlamydiaceae, in that compact electron-dense and larger replicative forms were seen in EM thin sections and in that electron-dense forms were never observed dividing. However, given the larger genome size of Simkania negevensis and its phylogenetic distance from the Chlamydiaceae, it was not surprising that differences were also observed. The growth cycle, as observed by phase-contrast microscopy, was longer (Kahane et al., 1999) and the morphology of electron-dense particles, as shown by EM, was somewhat different from chlamydial EBs. These particles were $0 \cdot 2-0 \cdot 3 \mu \mathrm{m}$ in diameter and usually contained some electron-lucent areas in addition to areas of condensed DNA; replicative forms were more pleomorphic than Chlamydiaceae RBs, usually being elongated with dimensions of $0 \cdot 3-0.7 \mu \mathrm{m}$, and without areas of condensed DNA (Fig. 2). The multiple, small, intertwining inclusions seen by EM in cells infected with Simkania negevensis (Fig. 2e, f) contrasted with the single inclusions which are seen in Chlamydia trachomatis-infected cells, and which are generated by the fusion of multiple inclusions (Ridderhof \& Barnes, 1989). The Simkania negevensis inclusions were more similar to the multiple inclusions seen in cells infected with Chlamydia psittaci (Hodinka \& Wyrick, 1986).

In the present study, we extended our original observations that the phenotypic replication cycle of Simkania negevensis takes about 12-15 days, while the number of IFUs produced increases exponentially for only 2-4 days, after which time a plateau is reached (Kahane et al., 1999). The photomicrographs of fixed and stained infected cells obtained in this study (Fig. 1) clearly show the accumulation of bacterial particles with time in the infected cells, as well as the relative lack of spread of the infection to neighbouring uninfected cells. Growth curves obtained at lower m.o.i. values (Fig. 3) also suggested that the infection does not spread to neighbouring cells, and that infectious particles are not released in significant amounts into the culture medium. The significance of the long plateau stage of the growth cycle during which cytopathic effects increased, but the organisms appeared to be 'trapped' in their host cells, is not understood. We found that four sequential 'rapid' passages of organisms present at 3-4 days p.i. did not result in a decrease of infectious yields, as compared to four 'long' sequential passages of 10 days duration (data not shown). This would seem to indicate that at least under in vitro conditions, there is no need for 'maturation', which might be postulated to be taking place during the long plateau period. However, the stationary phase may result in some survival advantage for the organisms during transmission in nature. Cells infected with Chlamydia trachomatis L2 detach from the monolayer or lyse by 2 days after infection; uninfected neighbouring cells are rapidly infected (data not shown). On the other hand, cells infected with the more distantly related intracellular bacterium Coxiella burnetii show minimal cytopathic effects and it has been suggested that this organism may lack an efficient membranolytic 
system (Heinzen et al., 1999); however, infectious forms can be mechanically released from infected cells early in the developmental cycle (Howe \& Mallavia, 2000).

The first hint that Simkania negevensis replicative forms may be infectious was the similar kinetics of growth of particles from the $44 / 52 \%$ and $40 / 44 \%$ Urografin fractions (Fig. 4). This possibility was lent more credibility by the fact that in growth curves, progeny infectivity increased not simultaneously with the appearance of electron-dense forms in EM thin sections, but earlier (Fig. 5), and received further support from the results of infectivity experiments done with purified $44 / 52 \%$ and $40 / 44 \%$ fractions (Table 1 ). In control experiments, using Chlamydia trachomatis, EBs totally accounted for the infectivity found in the 40/44\% fraction, but this was not the case for Simkania negevensis. The infectivity of particles appearing to be in transition between the larger replicative form and the more compact electron-dense form is not known. For the calculations, transition particles showing either a dense area or an unstained area were counted as dense forms and presumed to be infectious. Counting these particles as dense forms may have resulted in an overestimation of the level of such forms in the 40/44\% fraction and, therefore, may have led to an overestimation of their relative contribution to the infectivity in the $40 / 44 \%$ fraction. Nevertheless, the data indicate that in the case of Simkania negevensis, infectivity was apparently not limited to the dense forms.

Since the genome of Simkania negevensis is nearly twice the size of the Chlamydia trachomatis genome (Kahane et al., 1999), it is possible that additional genes permitting infectivity of all morphological forms are present in Simkania negevensis. If Simkania negevensis replicative forms are indeed infectious it may be predicted that these particles might be characterized by a physical stability comparable to that of the electron-dense forms, in contrast to Chlamydiaceae RBs which are osmotically fragile and incapable of infecting cells (Moulder, 1985; Tamura et al., 1967). Preliminary evidence suggests that Simkania negevensis replicative forms have a survival curve similar to that of electron-dense forms after exposure to various temperatures and to osmotic shock (unpublished data). More extensive studies comparing the morphological forms of Simkania negevensis are necessary; examination of the similarities and differences in membrane composition is of special interest.

It is notable that the growth cycle of Coxiella burnetii, which belongs to the order Rickettsiales (family Rickettsiaceae), includes two forms, a 'small cell variant' and a 'large cell variant', both of which are infectious (Wiebe et al., 1972). Our results raise questions as to the role played by electron-dense bodies and larger bodies in the growth cycles of newly described Chlamydia-like micro-organisms, some of which have not yet been grown in cell culture (Fritsche et al., 2000; Ossewarde \& Meijer, 1999), including members of the Parachlamydiaceae and Waddliaceae, in the order Chlamydiales
(Everett et al., 1999). Also, more general questions are raised as to the potential significance of Simkania negevensis morphological forms in the pathogenesis or epidemiology of infection by this novel micro-organism.

\section{ACKNOWLEDGEMENTS}

This study was supported by grant no. 95-119 from the United States-Israel Binational Science Foundation (BSF), Jerusalem, Israel, and by grant no. 3214 from the Office of the Chief Scientist of the Israel Ministry of Health. We thank M. Mathias for her assistance with EM, M. Yanai-Inbar for her assistance with light microscope photography, M. Werzberger for his helpfulness in the preparation of the colour prints, E. Mutzafi for his contributions and Dr Karin Everett for her constructive criticism of the manuscript and for helpful suggestions.

\section{REFERENCES}

Barbour, A. G., Amano, K.-I., Hackstadt, T., Perry, L. \& Caldwell, H. (1982). Chlamydia trachomatis has penicillin-binding proteins but not detectable muramic acid. J Bacteriol 151, 420-428.

Biberfeld, P. (1971). Cytological studies on blood lymphocytes activated by phytohemagglutinin in vitro. Acta Pathol Microbiol Scand 223, 7-8.

Birtles, R. J., Rowbotham, T. J., Storey, C., Marrie, T. J. \& Rauolt, D. (1997). Chlamydia-like obligate intracellular parasite of freeliving amoebae. Lancet 349, 925-926.

Caldwell, H. D., Kromhout, J. \& Schachter, J. (1981). Purification and partial characterization of the major outer membrane protein of Chlamydia trachomatis. Infect Immun 31, 1161-1176.

Everett, K. D. E., Bush, R. M. \& Andersen, A. A. (1999). Emended description of the order Chlamydiales, proposal of Parachlamydiaceae fam. nov. and Simkaniaceae fam. nov., each containing one monotypic genus, revised taxonomy of the family Chlamydiaceae, including a new genus and five new species, and standards for the identification of organisms. Int J Syst Bacteriol 49, 415-440.

Friedman, M. G., Galil, A., Greenberg, S. \& Kahane, S. (1999). Seroprevalence of IgG antibodies to the Chlamydia-like microorganism 'Simkania Z' by ELISA. Epidemiol Infect 122, 117-123.

Fritsche, T. R., Horn, M., Wagner, M., Herwig, R. P., Schleifer, K.-H. \& Gautom, R. K. (2000). Phylogenetic diversity among geographically dispersed Chlamydiales endosymbionts recovered from clinical and environmental isolates of Acanthamoeba spp. Appl Environ Microbiol 66, 2613-2619.

Glauert, A. M. (1975). Fixation, dehydration and embedding of biological specimens. In Practical Methods in Electron Microscopy, p. 48. Edited by A. M. Glauert. Amsterdam: North Holland Publishing Company.

Gonen, R., Shemer-Avni, Y., Csàngo, P. A., Sarov, B. \& Friedman, M. G. (1993). Serum reactivity to Chlamydia trachomatis and C. pneumoniae antigens in patients with documented infection and in healthy children by microimmuno-fluorescence and immunoblotting techniques. APMIS 101, 719-726.

Heinzen, R. A., Hackstadt, T. \& Samuel, J. E. (1999). Developmental biology of Coxiella burnetii. Trends Microbiol 7, 149-154.

Higashi, N. (1965). Electron microscopic studies on the mode of reproduction of trachoma virus and psittacosis virus in cell cultures. Exp Mol Pathol 4, 24-39. 
Higashi, N., Tamura, A. \& Iwanaga, M. (1962). Developmental cycle and reproductive mechanism of the meningopneumonitis virus in strain L cells. Ann N Y Acad Sci 98, 100-121.

Hondinka, R. L. \& Wyrick, P. B. (1986). Ultrastructural study of mode of entry of Chlamydia psittaci into L-929 cells. Infect Immun 54, 855-863.

Howe, D. \& Mallavia, L. P. (2000). Coxiella burnetii exhibits morphological change and delays phagolysosomal fusion after internalization by J774A.1 cells. Infect Immun 68, 3815-3821.

Kahane, S., Gonen, R., Sayada, C., Elion, J. \& Friedman, M. G. (1993). Description and partial characterization of a new Chlamydia-like microorganism. FEMS Microbiol Lett 109, 329-334.

Kahane, S., Greenberg, D., Friedman, M. G., Haikin, H. \& Dagan, R. (1998). High prevalence of 'Simkania Z', a novel Chlamydialike bacterium, in infants with acute bronchiolitis. J Infect Dis 177, 1425-1429.

Kahane, S., Everett, K. D. E., Kimmel, N. \& Friedman, M. G. (1999). Simkania negevensis strain $\mathrm{Z}^{\mathrm{T}}$ : growth, antigenic and genome characteristics. Int J Syst Bacteriol 49, 815-820.

Lieberman, D., Kahane, S., Lieberman, D. \& Friedman, M. G. (1997). Pneumonia with serological evidence of acute infection with the Chlamydia-like microorganism ' $\mathrm{Z}$ '. Am J Respir Crit Care Med 156, 578-582.

Moulder, J. W. (1985). Comparative biology of intracellular parasitism. Microbiol Rev 49, 298-337.
Ossewarde, J. M. \& Meijer, A. (1999). Molecular evidence for the existence of additional members of the order Chlamydiales. Microbiology 145, 411-417.

Rake, G. W. (1957). Family Chlamydiaceae fam. nov. In Bergey's Manual of Determinative Bacteriology, 7th edn, pp. 957-968. Edited by R. S. Breed, E. G. D. Murray \& N. R. Smith. Baltimore: Williams \& Wilkins.

Ridderhof, J. C. \& Barnes, R. C. (1989). Fusion of inclusions following superinfection of HeLa cells by two serovars of Chlamydia trachomatis. Infect Immun 57, 3189-3193.

Schachter, J. (1999). Infection and disease epidemiology. In Chlamydia: Intracellular Biology, Pathogenesis, and Immunity, pp. 139-169. Edited by R. S. Stephens. Washington, DC: American Society for Microbiology.

Tamura, A., Matsomoto, A. \& Higashi, N. (1967). Purification and chemical composition of reticulate bodies of the meningopneumonitis organisms. J Bacteriol 93, 2003-2008.

Wiebe, M. E., Burton, P. R. \& Shankel, D. M. (1972). Isolation and characterization of cell types of Coxiella burnetii phase I. J Bacteriol 110, 368-377.

Received 23 February 2001; revised 26 June 2001; accepted 22 October 2001. 